\title{
Laboratory and numerical study of waves in the port area
}

\author{
Лабораторные и численные исследования волн \\ в акватории порта
}

\author{
I.G. Kantardgi, \\ National Research Moscow State University of Civil \\ Engineering, Moscow, Russia \\ M.J. Zheleznyak, \\ Institute of Environmental Radioactivity, Fukushima \\ University, Fukushima, Japan
}

\author{
Д-р техн. наук, профрессор И.Г. Кантаржи, \\ Национальный исследовательский \\ Московский государственный \\ строительный университет, г. Москва, \\ Россия \\ канд. физ.-мат. наук, профрессор \\ М.И. Железняк, \\ Институт радиологии окружающей среды, \\ Университет Фукусима, г. Фукусима, \\ Япония
}

Ключевые слова: волны в акватории порта; эксперименты и численное моделирование; метод сопоставления; стоячие волны
Key words: port area waves; experiments and numerical modelling; method of comparison; standing waves

Abstract. Parameters of waves in water area of the projected port are normally obtained using physical and numerical modelling. Physical modelling allows defininig structural details of the port's facilities and provides with information for the appropriate selection of a numerical model. The problems created by this approach are shown in the case study of the projected port in Vostok (East) Bay, the Sea of Japan. The experimental study of waves propagation in the port water area was carried out in the wave basin. The port area was reproduced at a scale of 1:50, and the modelling was conducted under the Froude number similarity. Experimental results are provided for the study of wave propagation in the port model from the effects of the waves of $5 \%$ exceedance probability. To confirm the results of the laboratory experiments, four relevant mathematical models were used, one of them is the ARTEMIS model which is based on gentle slopes equations. The heights of numerically modeled waves in the control points were compared with the waves measured with sensors-wave gauges. The calculated values at the control point and minimum and maximum values in a circular neighborhood with the radius of $30 \mathrm{~m}$ (1/4 of the average wavelength of $120 \mathrm{~m}$ ) were compared with the results of the experiments. The proposed approach allows comparing the results of physical modelling with the results of numerical modelling and selecting the appropriate numerical model based on the results of the comparison.

Аннотация. Параметры волн в акватории порта обычно получают путем физического и численного моделирования. Физическое моделирование позволяет определить конструктивные детали портовых сооружений и предоставляет информацию для выбора соответствующей численной модели. Проблемы, с которыми этот подход связан, показаны в исследовании проектируемого порта в бухте Восток, Японское море. Экспериментальное исследование распространения волн в акватории порта были проведены в волновом бассейне. Район порта был воспроизведен в масштабе 1:50, и моделирование проводилось по параметру подобия Фруда. Результаты эксперимента используются для изучения распространения волн в численной модели порта от воздействия волны 5\% обеспеченности. Чтобы подтвердить результаты лабораторных экспериментов, были использованы четыре соответствующие математические модели, одна из них ARTEMIS, основанная на уравнениях пологих склонов. Высоты волн численно моделируются и сравниваются с измерениями в контрольных точках датчиками волн. Рассчитанные значения в контрольной точке и минимальное и максимальное значения в круговой окрестности контрольной точки с радиусом 30 м (1/4 средней длины волны 120 м) сопоставлялись с результатами измерений. Предлагаемый подход позволяет сравнивать результаты физического моделирования с результатами численного моделирования и выбирать на основе результатов сравнения подходящую численную модель. 


\section{Introduction}

If the definition of calculated waves approaching the projected port facilities is subject to numerical simulation with verification by natural data, the impact of the waves on the port facilities is determined by numerical and physical modelling methods. Then, to verify the received data by physical modelling of the interaction of waves with models of constructions. That meets the requirements of the relevant regulatory documents [1, 2].

This approach has been adopted in most of the world's major centers of the world leading research port facilities [3-8]. When comparing the results of physical and numerical simulation of waves, it has solved the task of choosing the numerical model of wave propagation around port facilities $[4,5]$. Furthermore, this model is used to compare different design options. A typical task of the research of interaction of waves with port structures is the task of determining the waves on a protected water area of the port [9].

However, the analysis of published papers on numerical and physical modelling of wave propagation in the port water area shows that these works do not pay attention to detailed methodology of comparing the obtained wave heights, measured using the physical models and numerical modelling $[3,7]$.

For example, [7] shows only the results of numerical research. However, the problem of standing waves or crowding in the water is discussed in this work. However, the authors' experience shows that in a head-to-head comparison of the heights of waves generated by numerical and physical modelling, problems that require examination arise [9].

The task is considered by the example of the research using the methods of numerical and physical modelling of waves interaction with the projected port of Eastern petrochemical company.

The projected marine terminal is to be designed for shipping of finished/refined products and for receiving crude oil. Mooring facilities are located in Vostok Bay, the Sea of Japan. Vostok Bay is a part of the southeast side of Peter the Great Bay and intrudes the land for approximately $7.3 \mathrm{~km}$. The distance between its capes is about $5.8 \mathrm{~km}$ and the area of the water table is $38 \mathrm{sq}$. km with the length of the shoreline of about $29 \mathrm{~km}$. The open part of Vostok Bay faces the south-southwest direction.

The moorings disposition inside of the bay allows for designing the protection structures against the waves approaching only from the south and west. The layout of the breakwater and the moorings is shown in Figure 1.

The projected marine terminal is designed for procuring of a new refinery with the capacity of 30 million tons per year. The refinery is not built yet and the time of the construction is not predetermined yet.

To select an adequate mathematical model of wave propagation in the port water area, a standard approach is used to compare the results of numerical simulation of wave fields with measurements at certain points of the physical model. In this case, possible formation of partially standing waves in the port water area (physical model) can lead to difficulties in this comparison. A similar problem arose during the present study.

Laboratory and numerical studies of waves at the port water area were conducted to verify the effectiveness of the breakwater in providing of acceptable parameters of waves at the moorings, like in other authors' papers [10-12]. The aim of this paper is to discuss the technology of comparing the results of numerical and physical modelling of wave fields inside the port water area and to investigate this technology for the example of the designed port.

The actual normative methods [13-15] are available for the problem's solutions with serious limitations [16].

\section{Numerical and experimental study}

To study waves propagation, the physical model of the water area of the port was built in the wave basin of Moscow State Civil Engineering University (MSCEU). The study program was developed to investigate the distribution of $5 \%$ exceedance South and Southwest waves at the port water area and their impact on the eastern and western sides of the breakwater.

The scale of the model of 1:50 was determined according to the water basin size of $27 \times 27 \mathrm{~m}$, actual size of the port water area, distance from the wave generator to the entrance to the port, depth of 
the basin, prevailing wave direction, and the correspondence of wave processes in nature and in the model as per Froude's similarity criteria.

Physical modelling was conducted in a usual way for such tasks, by the criterion of Froude $\mathrm{Fr}=$ $\mathrm{h} / \mathrm{gT}^{2}$ in the conditions of auto modelling under Reynolds parameter. In accordance with the criterion of modelling individual elements, the weight of protective mounts on the model was defined as $m_{n}=m_{m} \lambda^{3}$, where $m_{n}$ is the mass of a single element in natural conditions, $m_{m}$ is the mass of the element in the model, the $\lambda$ is the linear scale of modelling.

Four series of experiments were conducted to study South and Southwest waves impact on the eastern and western sides of the breakwater.

At the eastern side of the breakwater, the experiments were conducted for South waves with the parameters of $T=12.3 \mathrm{~s}$ and $h_{5 \%}=5 \mathrm{~m}$ and for Southwest waves with the parameters of $T=10.4 \mathrm{~s}$ and $h_{5 \%}=5 \mathrm{~m}$. The modelling parameters were estimated as $\mathrm{T}=1.74 \mathrm{~s}, \mathrm{~h}_{5 \%}=10 \mathrm{~cm}$, and $\mathrm{T}=1.5 \mathrm{~s}$, $h_{5 \%}=10.0 \mathrm{~cm}$, respectively.

At the western side of the breakwater, the experiments were conducted for South waves with the parameters of $\mathrm{T}=12.3 \mathrm{~s}, \mathrm{~h}_{5 \%}=8.5 \mathrm{~m}$, and for Southwest waves with the parameters of $\mathrm{T}=10.4 \mathrm{~s}$, $\mathrm{h}_{5 \%}=7.2 \mathrm{~m}$. The modelling parameters were estimated as $\mathrm{T}=1.74 \mathrm{~s}, \mathrm{~h}_{5 \%}=17 \mathrm{~cm}$ and $\mathrm{T}=1.47 \mathrm{~s}$, $\mathrm{h}_{5 \%}=14.4 \mathrm{~cm}$, respectively.

The description of the study and the results of the physical and numerical experiments related to South waves with diffraction on the western side of the breakwater is provided below.

The locations of wave sensors and the wave generator in the wave basin are shown in Figure 2. Different numerical models are used to calculate shallow waves and waves at the water area of water ports. The spectral model SWAN $[17,18]$ is used worldwide, and it is open-source software.

The model is based on the wave action density balance equation (or conservation of energy under no ambient currents condition) with the source and sink terms. The model can be used in Cartesian or spherical coordinates depending on the scale of applications. Diffraction processes are described approximately and cannot provide a detailed wave field solution for wave interactions with hydrotechnical structures.

Different mathematical models were used to obtain the calculated field waves and comparisons with the results of physical modelling of waves in the port water area: SWAN, SWAN 123 (spectral version), WaveWatch III, and ARTEMIS. And to get the final results, the model SWAN (waves on the way to port installations) and the model ARTEMIS (waves in the port water area) were used.

The results of physical modelling were compared with the results of numerical modelling conducted using the ARTEMIS software [19]. Software ARTEMIS is based on the gentle slope hydrodynamic equations [20, 21]. The software solves the waves transformation in coastal zones including the processes of refraction-diffraction, bottom friction energy dissipation and breaking of waves. The finite element numerical method is utilized to solve the elliptic equations. ARTEMIS is successfully used for similar studies [3]. It is open source software and can be found at http://www.opentelemac.org/ [22].

Кантаржи И.Г., Железняк М.И. Лабораторные и численные исследования волн в акватории порта // Инженерно-строительный журнал. 2016. № 6(66). С. 49-59. 


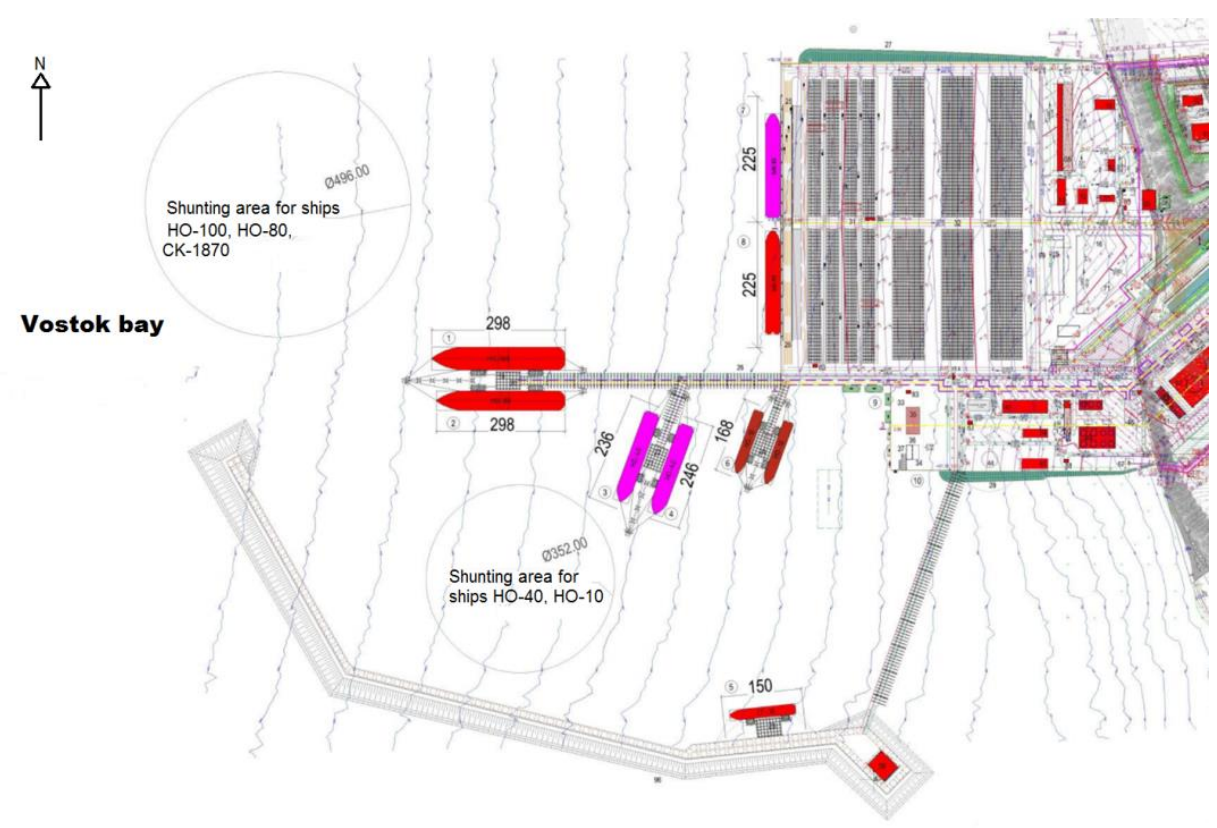

Figure 1. Marine Terminal Layout. Dimensions are in meters

The bathymetric map of the Sea of Japan, Peter the Great Bay, and Vostok Bay, with the scale of $1: 25000$ obtained by the echo-sounder survey was digitized and used for numerical modelling. The port's structures were included into the digitized map.

Waves interaction with different types of structures was considered by introducing the reflection coefficients along the structures' boundaries. The reflection coefficient of $\mathrm{kr}=0.9$ was used for vertical structures and for the side slopes of the wave canal. The reflection coefficient of 0.5 was used for the slopes of the structures protected by an armor berm.

Two types of the breakwater were considered. The main type was a wave impermeable structure with a revetment slope. The alternative type was a structure with a wave permeable central part that allows some waves to get to the water area of the port (Figure 4).

The revetment slope was designed with three layers of protection: the bottom layer made of stones with weights from 50 to $150 \mathrm{~kg}$ was overlayed by the layer made of stones from 500 to $1500 \mathrm{~kg}$, and the top layer was made of shaped concrete units (hexabits) with weight of 10 tones.

To obtain the reflection coefficients, the laboratory experiments of incoming and passing waves were conducted in a wave flume and wave's parameters were recorded. Scale modelling in the flume was selected as 1:25. The example of the setup of a pier with piles and a surge plate (wave deflector to reduce wave overtopping) in the wave flume is presented in Figure 4. The reflection coefficient for impermeable structure breakwater (Figure 3 ) was obtained as 0.5 , the reflection coefficient for wave permeable breakwater with a surge plate (Figure 4) was obtained as 0.65 .

To absorb the waves at the wavemarker's back side for both wave flume and in the basin, the permeable slope construction with metal shavings was used (Figure 5). Methodical experiments show that this design provides a coefficient of wave reflection no higher than $2 \%$. 


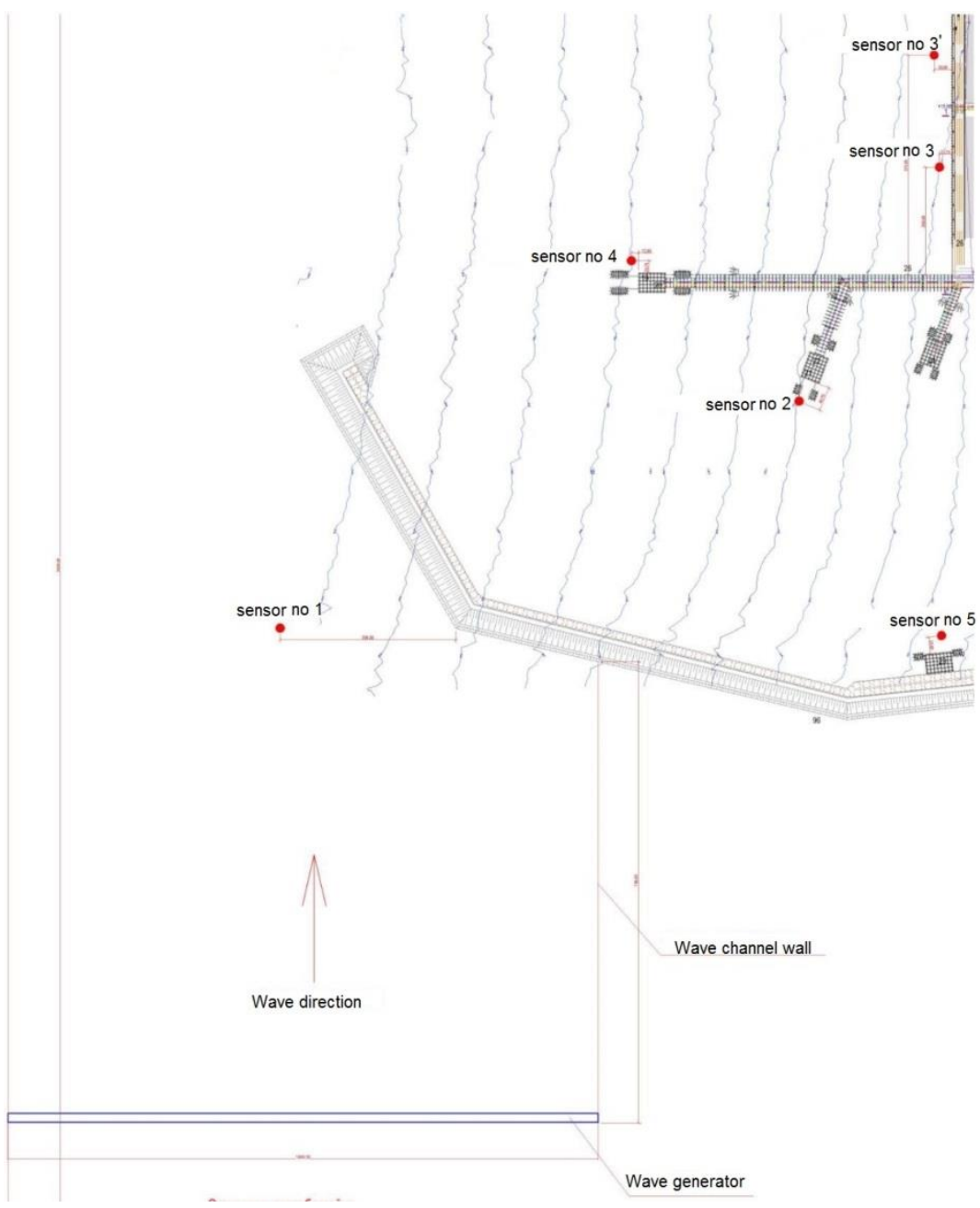

Figure 2. Marine terminal model layout with the locations of wave sensors and the wave generator. South waves impact on the western side of the breakwater study

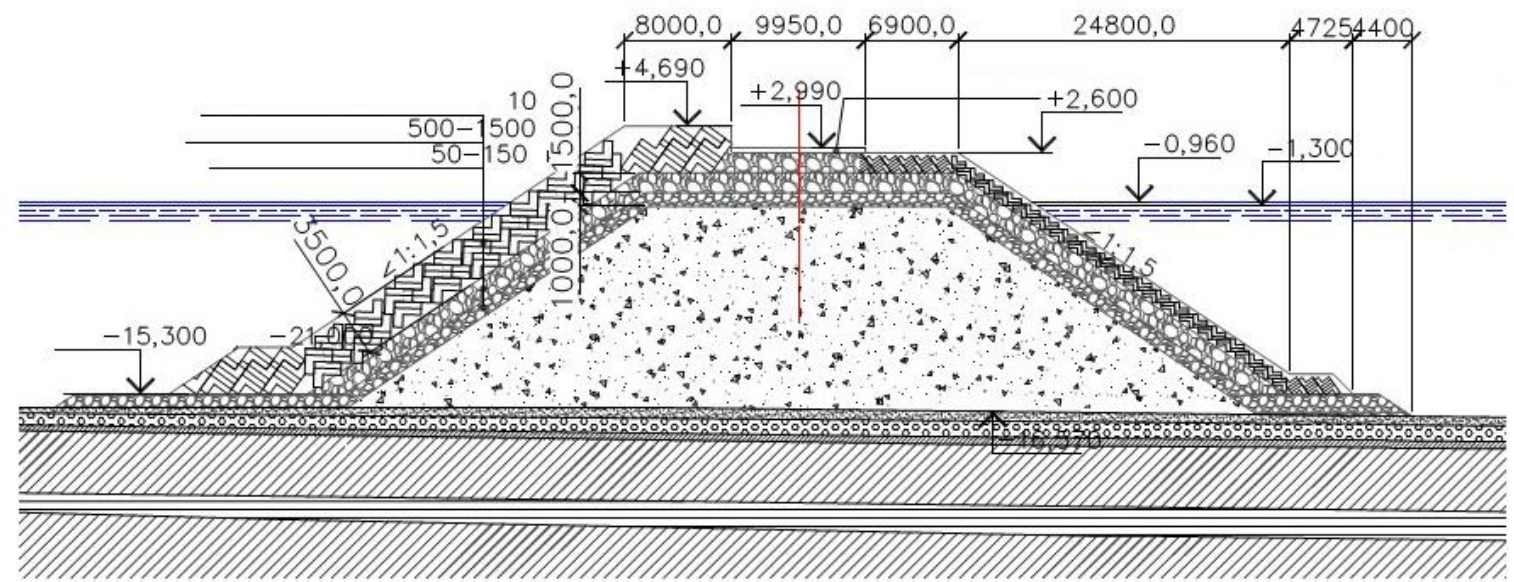

Figure 3. Cross section of the protected breakwater, slope type.

Horizontal sizes are in millimeters, vertical levels are shown in meters, Baltic System

The bathymetry of the calculation domain for the study of the western side of the breakwater and South waves is shown in Figure 6.

ARTEMIS numerical grids were built in accordance with the numerical modelling requirements. It means that there should be no less than grid's 7 nodes for the wave length. The grids were built for the monochromatic wave with the period of 7 secs and for the number of nodes of 10 . The mesh sizes changed from $2 \mathrm{~m}$ for shallow water to $8 \mathrm{~m}$ for deep water. The sizes of grids were as following: for the

Кантаржи И.Г., Железняк М.И. Лабораторные и численные исследования волн в акватории порта // Инженерно-строительный журнал. 2016. № 6(66). С. 49-59. 
study of the eastern side of the breakwater and South waves the number of nodes was 87959 and the number of elements was 174018; for the study of the eastern side of the breakwater and Southwest waves the number of nodes was 88969 and the number of elements was 175945; for the study of the western side of the breakwater and South waves the number of nodes was 81581 and the number of elements was 161487; for the study of the western side of the breakwater and Southwest waves the number of nodes was 51317 and the number of elements was 101413.

The bathymetry of the calculation domain to study the western side of the breakwater and South waves is shown in Figure 6.

The waves' parameters generated by the wave generator in physical modelling for South waves were $T=1.74 \mathrm{~s}$ and $h_{5 \%}=17.0 \mathrm{~cm}$ at the sensor's location 1 (entrance to the port). The corresponding parameters in the numerical modelling were $T=12.3 \mathrm{~s}, h_{5 \%}=8.5 \mathrm{~m}$, and the values were assigned to the wave generating boundary (Figure 6). The location of the wave-generating boundary in the numerical model corresponds to the location of the wave generator in the physical model.

The results of the numerical modelling of the wave fields are presented in Figures 7 and 8.

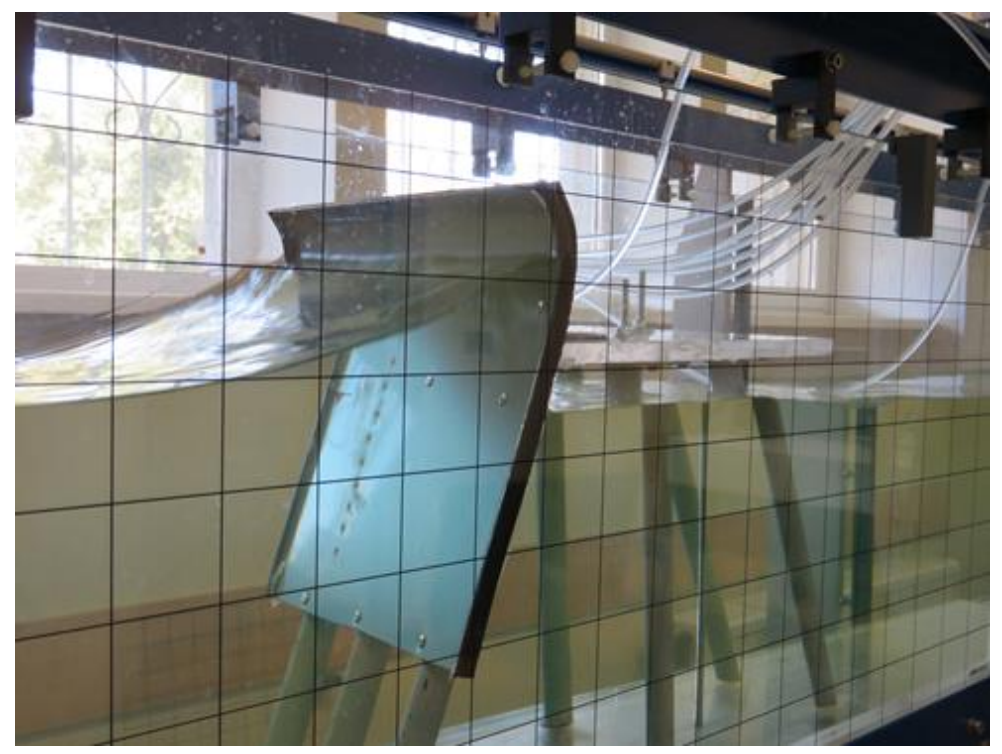

Figure 4. Experiment setup for estimating reflection coefficients of complex structures

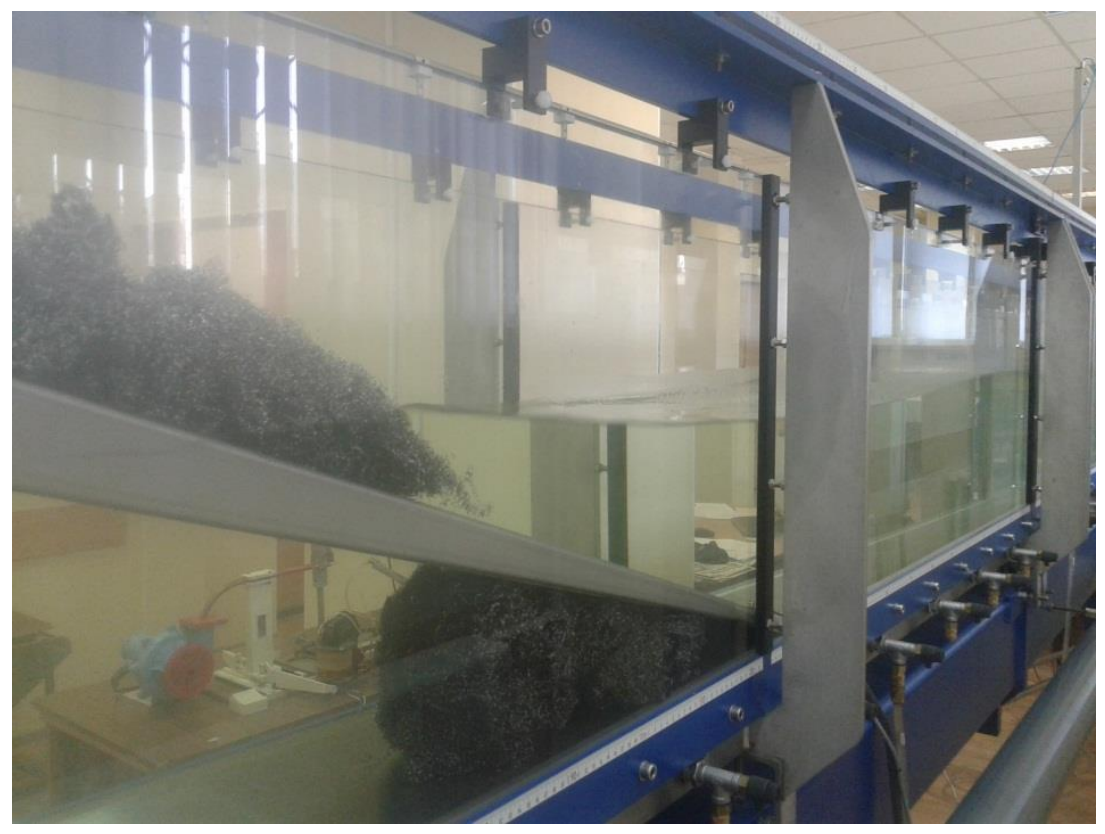

Figure 5. Wave absorber in the wave flume

Kantardgi I.G.,Zheleznyak M.J. Laboratory and numerical study of waves in the port area. Magazine of Civil Engineering. 2016. No. 6. Pp. 49-59. doi: 10.5862/MCE.66.5 


\section{Results and Discussion}

General pictures of the wave fields recorded during physical modelling are similar to the obtained result with numerical modelling. The numerical modelling exhibits the same diffraction and turn of the wave front at the breakwater head and propagation of the wave further to the diffraction area of the port (Figure 7). The general view of the wave field of the physical model is shown in Figure 9.

The waves' heights obtained during physical modelling and converted to natural values are summarized in Table 1. The results of numerical modelling are also presented in Table 1.

The calculated waves' heights at the sensor locations 1, 3', and 4 are similar to the measured ones, but at the sensor locations 2, 3, and 5 they are somewhat different from the measured ones. Nevertheless, all obtained results fall to the interval from the minimum to maximum calculated values, inside of $30 \mathrm{~m}$ radius with centers at the sensor locations.

Table 1. Wave heights obtained by the ARTEMIS model and recorded during physical modelling for the study of the South waves impact on the western side of the breakwater. The min and max values of the calculated heights are the calculated values inside of the circle with the radius of $30 \mathrm{~m}$ with the center at the sensor location.

\begin{tabular}{|c|c|c|c|c|c|c|}
\hline \multirow{2}{*}{$\begin{array}{l}\text { Control } \\
\text { location }\end{array}$} & \multirow{2}{*}{$\begin{array}{l}\text { Measured wave } \\
\text { height, } \mathrm{m}\end{array}$} & \multirow{2}{*}{$\begin{array}{c}\text { Water depth } \\
\text { (physical model), } \\
\text { m }\end{array}$} & \multicolumn{3}{|c|}{ Calculated wave height, $\mathrm{m}$} & \multirow{2}{*}{$\begin{array}{c}\text { Water depth } \\
\text { (numerical } \\
\text { model), m }\end{array}$} \\
\hline & & & $\begin{array}{l}\text { Control } \\
\text { point }\end{array}$ & $\min$ & $\max$ & \\
\hline 1 & 8.5 & 22 & 8.21 & 7.00 & 10.02 & 20.59 \\
\hline 2 & 1.01 & 15 & 0.45 & 0.02 & 1.67 & 14.99 \\
\hline 3 & 0.74 & 13 & 2.32 & 0.21 & 4.45 & 13.00 \\
\hline $3^{\prime}$ & 0.94 & 13.5 & 0.99 & 0.23 & 3.9 & 13.47 \\
\hline 4 & 1.61 & 18 & 2.12 & 1.28 & 2.78 & 18.00 \\
\hline 5 & 0.62 & 11.5 & 0.37 & 0.22 & 0.69 & 11.39 \\
\hline
\end{tabular}

The graphical representation of the calculated and measured values is shown in Figure 10.

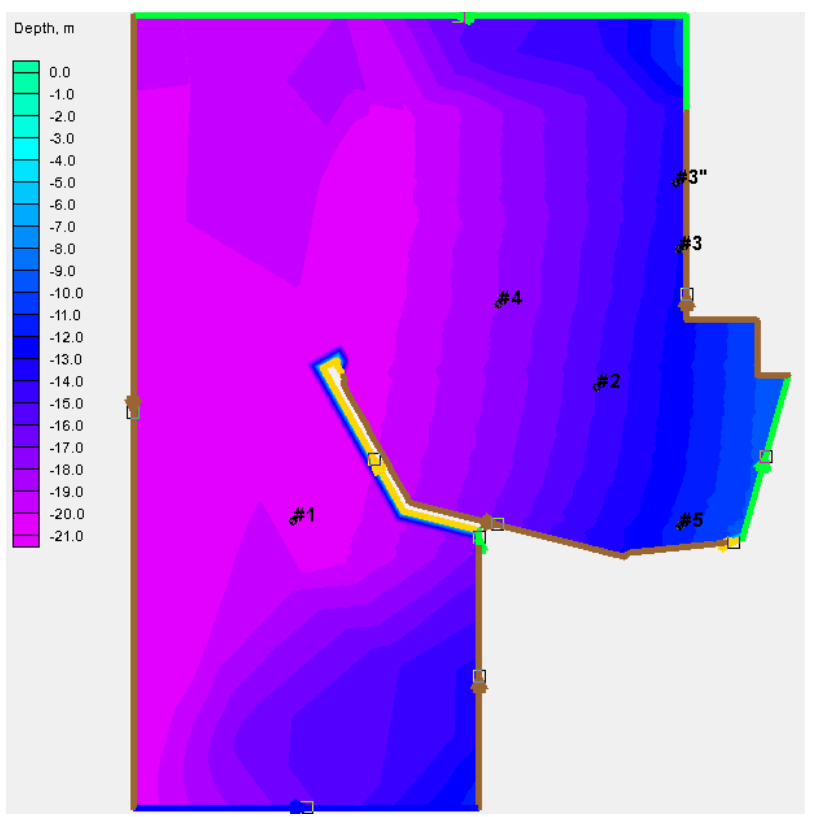

Figure 6. Modelling domain of the study of the South Waves impact on the western side of the breakwater. The wave-generating boundary is in blue.

Free boundaries are in green. Other boundaries are reflecting boundaries with $\mathrm{kr}=0.9$ (brown), $\mathrm{kr}=0.5$ (yellow). The control locations 1, 2, 3, 3', 4, and 5 correspond to the locations of the wave sensors during physical modelling 
One of the reasons for the difference between the wave heights, measured and calculated, can be that the wave field for the monochromatic wave is significantly inhomogeneous and shows changes in a series of maximums and minimums. As a result of frequent waves' reflections and interferences, the partial standing waves occur at the port water area. Thus, significant changes in the wave heights at the control location can be observed. Correspondingly, in spite of the similarity of the wave fields of physical and numerical modelling, a small offset of the minimums and maximums can lead to a significantly different result at the control location. However, within the definite distance from the control locations, the calculated heights close to the measured ones can be found. Therefore, to compare the results, the calculated values within the radius of $30 \mathrm{~m}$ or a $1 / 4$ of the average wave length of $120 \mathrm{~m}$ were considered and are shown in Table 1. The results of the measured values reside in the minimum maximum interval for all control locations. The same method of comparing the calculated and measured results was applied to the other three studies, and the same trend was observed.

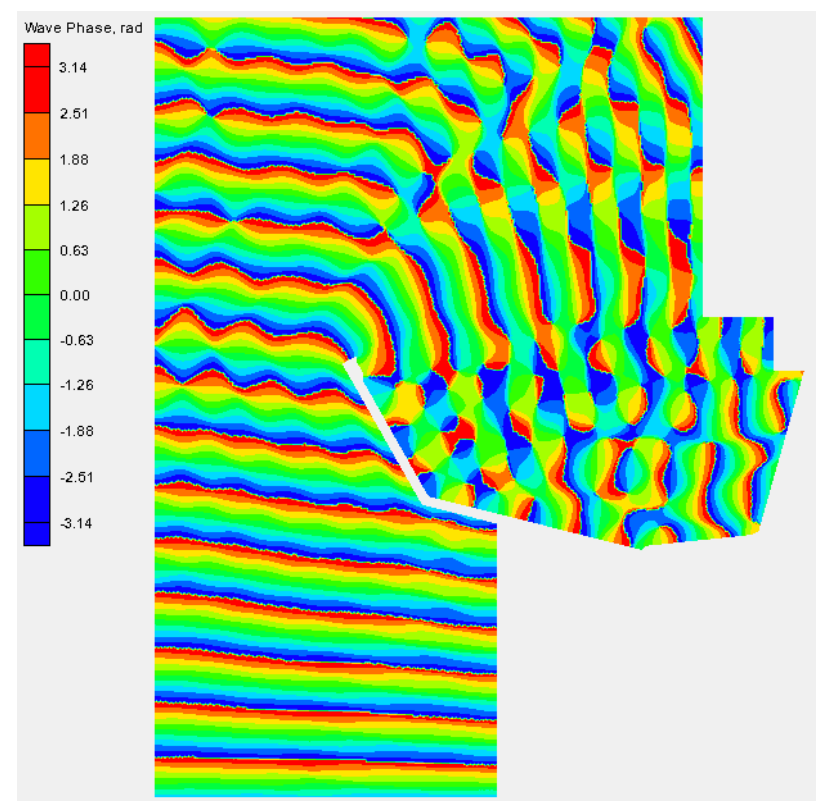

Figure 7. Calculated waves phases for the physical model of the port water area for the study of the South Waves impact on the western side of the breakwater

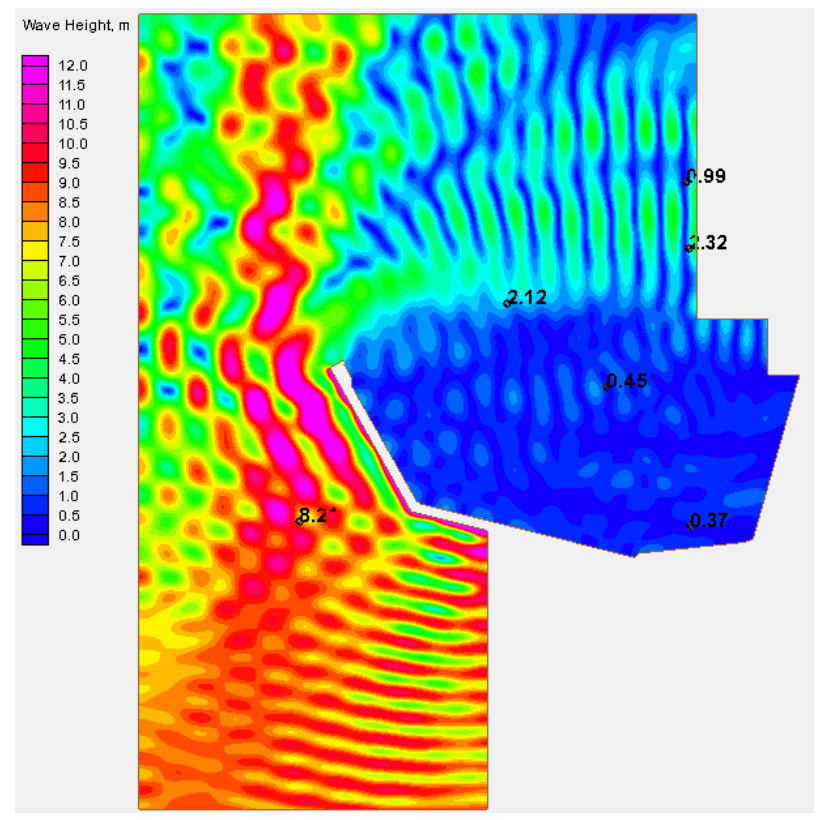

Figure 8. Calculated wave heights for the physical model of the port water area for the study of the South Waves impact on the western side of the breakwater. Wave heights are shown in colors and in numbers at the control locations 


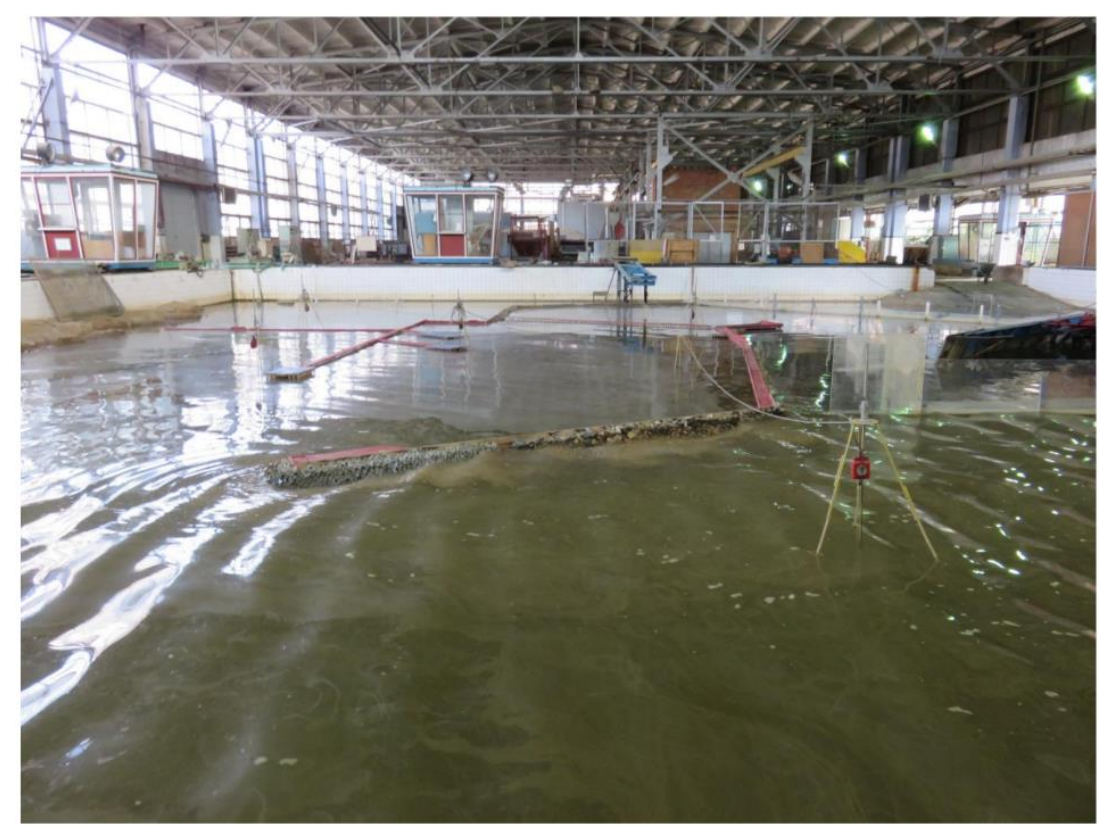

Figure 9. General view of the wave field generated by South Waves during physical modelling

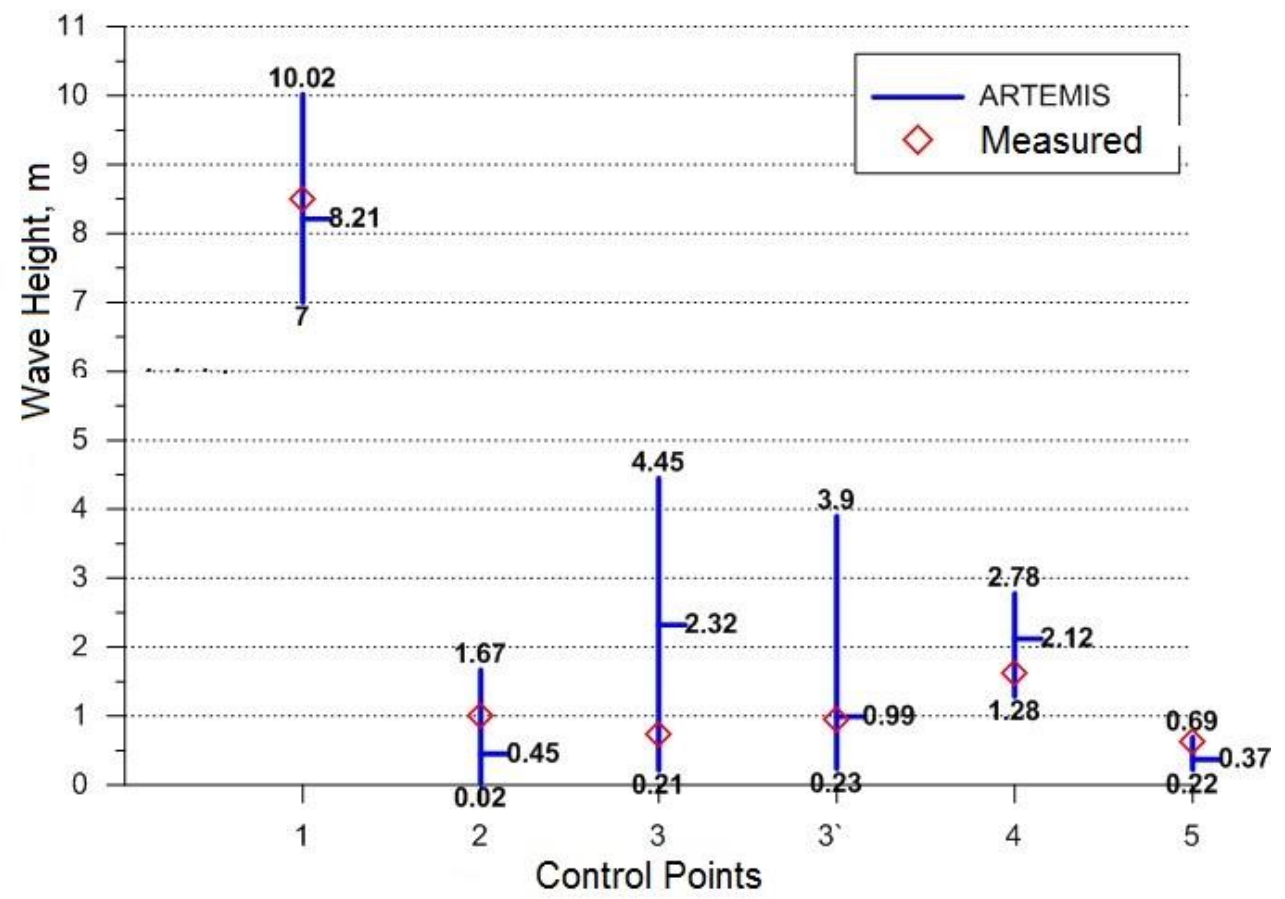

Figure 10. Measured and calculated wave heights.

Study of the South Waves impact on the western side of the breakwater

In published works of other authors, a detailed comparison of wave fields on the water area of the port derived from physical and numerical modelling was not touched upon.

\section{Conclusions}

When comparing the results of physical and numerical modelling of the wave field at the port water area, the phenomenon of forming partial standing waves with different intensities at different locations should be considered. In the case of the partial standing wave occurrence, the calculated and measured heights of waves at the corresponding locations can be significantly different. It is recommended to compare the calculated results with the measured results within the radius of a $1 / 4$ of the average wave length from the location where the waves were measured. The calculated maximum and minimum wave

Кантаржи И.Г., Железняк М.И. Лабораторные и численные исследования волн в акватории порта // Инженерно-строительный журнал. 2016. № 6(66). С. 49-59. 
heights within the radius and the calculated wave height at the control location should be used to compare with the measured result at the control location.

The approach to comparing the results has been used to study waves at the water area of the projected oil-tanker port at Vostok Bay, the Sea of Japan. The approach also allows determining the use of the numerical model of wave diffraction.

The obtained research results allowed choosing the numerical model used to study options for the design of protective structures of the projected port.

\section{References}

1. Kantarzhi I.G., Kuznetsov K.I. Naturnyye izmereniya volneniya pri opredelenii nagruzok na morskiye gidrotekhnicheskiye sooruzheniya [In site measurement of waves for determination of loads onto sea hydraulic structures]. Magazine of Civil Engineering. 2014. No. 4(48). Pp. 49-62. (rus)

2. Kantarzhi I.G. Fizicheskoye i chislennoye modelirovaniye voln u portovykh gidrotekhnicheskikh sooruzheniy. Beregovaya zona - vzglyad $v$ budushcheye [Physical and numerical modelling of waves and port structures. Coastal area - looking into the future]. Materialy XXV mezhdunarodnoy beregovoy konferentsii [Proceeding of international coastal conference]. 2014, Sochi: Izd-vo GEOS, 2014. Vol. 2. Pp. 128-131. (rus)

3. Kofoed-Hansen H., Sloth P., Sørensen O.R., Fuchs J Combined numerical and physical modelling of seiching in exposed new marina. Proceedings of 27th international conference of coastal engineering. 2000. Pp. 3600-3614.

4. Smit P., Stelling G., Zijlema M. Assessment of nonhydrostatic wave-flow model SWASH for directionally spread waves propagating through a barred basin. Proceedings of ACOMEN 2011. 2011. Pp. 1-10.

5. Rijnsdorp D.P., Smit P.B., Zijlema M. Non-hydrostatic modelling of infragravity waves using SWASH. Proceedings of 33rd Conference on Coastal Engineering. 2012. Pp. 1287-1299.

6. Zijlema M., Stelling G., Smit P. SWASH: An operational public domain code for simulating wave fields and rapidly varied flows in coastal waters. Coastal Engineering. 2011. № 10(58). Pp. 992-1012.

7. Divinskiy B.V., Kosyan R.D., Kuklev S.V. Parametry vetrovogo volneniya na zashchishchennykh akvatoriyakh [Wind waves parameters in protected water bodies] Fundamentalnaya i prikladnaya gidrofizika [Fundemental and applied hydrophysics]. 2010. No. 4(10). Pp. 5-16. (rus)

8. Divinskiy B.V., Kosyan R.D., Podymov I.S., Pushkarev O.V. Ekstremalnoye volneniye $v$ severo-vostochnoy chast Chernogo morya $v$ fevrale $2003 \mathrm{~g}$. [Extreme waves in North-East part of the Black Sea in Feb/2003]. Oceanology. 2004. Vol. 43. No. 6. Pp. 2-15. (rus)

9. Kantarzhi I., Zuev N., Shunko N., Zeleznyak M., Dikiy P., Sorokin M. Numerical and physical modelling of the waves inside the new marina in Gelendjik (Black Sea). Application of physical modelling to port and coastal protection. Proceedings of 5th international conference Coastlab. Varna, 2014. Vol. 2. Pp. 253-262.

10. Dikiy P.V., Dzyuba N.N., Zheleznyak M.I., Sorokin M.V. Modelirovaniye volnovogo rezhima poberezhya Imeretinskoy nizmennosti [Modelling of the wave regime of Imeretinka coast]. International Journal for Computational Civil and Structural Engineering. 2011. No. 2(7). Pp. 5463. (rus)

11. Kantardgi I., Zheleznyak M., Demchenko R., Dykyi P., Kivva S., Kolomiets P., Sorokin M. Modelling of nonlinear hydrodynamics of the coastal areas of the Black Sea by the chain of the proprietary and open source models. Proceedings of EGU. Vienna, 2014. Pp. 113-119.

\section{Литература}

1. Кантаржи И.Г., Кузнецов К.И. Натурные измерения волнения при определении нагрузок на морские гидротехнические сооружения // Инженерностроительный журнал. № 4(48). 2014. С. 49-62.

2. Кантаржи И.Г. Физическое и численное моделирование волн у портовых гидротехнических сооружений. Береговая зона - взгляд в будущее // Материалы XXV международной береговой конференции. Сочи: Изд-во ГEOC, 2014. Т. 2. С. 128-131.

3. Kofoed-Hansen H., Sloth P., Sørensen O.R., Fuchs J. Combined numerical and physical modelling of seiching in exposed new marina // Proceedings of 27th international conference of coastal engineering. 2000. Pp. 3600-3614.

4. Smit P., Stelling G., Zijlema M. Assessment of nonhydrostatic wave-flow model SWASH for directionally spread waves propagating through a barred basin // Proceedings of ACOMEN 2011. 2011. Pp. 1-10.

5. Rijnsdorp D.P., Smit P.B., Zijlema M. Non-hydrostatic modelling of infragravity waves using SWASH // Proceedings of 33rd Conference on Coastal Engineering. 2012. Pp. 1287-1299.

6. Zijlema M., Stelling G., Smit P. SWASH: An operational public domain code for simulating wave fields and rapidly varied flows in coastal waters // Coastal Engineering. 2011. № 10(58). Pp. 992-1012.

7. Дивинский Б.В., Косьян Р.Д., Куклев С.В. Параметры ветрового волнения на защищенных акваториях // Фундаментальная и прикладная гидрофизика. 2010. № 4(10). С. 5-16.

8. Дивинский Б.В., Косьян Р.Д., Подымов И.С., Пушкарев О.В. Экстремальное волнение в северо-восточной части Черного моря в феврале 2003 г. // Океанология. 2004. T. 43. № 6.C. 2-15.

9. Kantarzhi I., Zuev N., Shunko N., Zeleznyak M., Dikiy P., Sorokin M. Numerical and physical modelling of the waves inside the new marina in Gelendjik (Black Sea). Application of physical modelling to port and coastal protection // Proceedings of 5th international conference Coastlab. Varna, 2014. Vol. 2. Pp. 253-262.

10. Дикий П.В., Дзюба Н.Н., Железняк М.И., Сорокин М.В. Моделирование волнового режима побережья Имеретинской низменности // International Journal for Computational Civil and Structural Engineering. 2011. № 2(7). C. 54-63.

11. Kantardgi I., Zheleznyak M., Demchenko R., Dykyi P., Kivva S., Kolomiets P., Sorokin M. Modelling of nonlinear hydrodynamics of the coastal areas of the Black Sea by the chain of the proprietary and open source models /I Proceedings of EGU. Vienna, 2014. Pp. 113-119.

12. Кантаржи И.Г. Уточнение расчетных элементов волн и льда для определения нагрузок на морские гидротехнические сооружения на основе натурных наблюдений // Гидротехническое строительство. 2014. № 1. C. 21-33.

13. Руководство по определению нагрузок и воздействий на гидротехнические сооружения (волновых, ледовых и от судов). Л: ВНИИГ имени Б.Е. Веденеева, 1977.

Kantardgi I.G.,Zheleznyak M.J. Laboratory and numerical study of waves in the port area. Magazine of Civil Engineering. 2016. No. 6. Pp. 49-59. doi: 10.5862/MCE.66.5 
12. Kantarzhi I.G. Utochneniye raschetnykh elementov voln i Ida dlya opredeleniya nagruzok na morskiye gidrotekhnicheskiye sooruzheniya na osnove naturnykh nablyudeniy [Development of design parameters of waves to define the design loads onto sea hydraulic strucutures on the basr of in field observations]. Gidrotekhnicheskoye stroitelstvo [Hydraulic structures]. 2014. No. 1. Pp. 21-33. (rus)

13. Rukovodstvo po opredeleniyu nagruzok i vozdeystviy na gidrotekhnicheskiye sooruzheniya (volnovykh, ledovykh $i$ ot sudov) [Manual on determination of loads and impacts onto the hydraulic structures (of waves, ice, and boats)]. Leningrad: VNIIG imeni B.Ye. Vedeneyeva, 1977. 254 p. (rus)

14. SP 38.13330.2012. Nagruzki i vozdeystviya na gidrotekhnicheskiye sooruzheniya (volnovyye, ledovyye $i$ ot sudov) [Loads and impacts on hydrotekhnical structures (of waves, ice and boats)]. Moscow. Minregion Rossii, 2011. 116 p. (rus)

15. $R D$ 31.33.02-81. Metodicheskiye ukazaniya po opredeleniyu vetrovykh $i$ volnovykh usloviy pri proyektirovanii morskikh portov [Manual on wind and wave conditions in design of the sea ports]. Moscow: SoyuzmorNIlproyekt. 1981. 91 p. (rus)

16. Galenin B.G., Duginov B.A., Krivickij S.V., Krylov Ju.M., Podmogil'nyj I.A., Poljakov Ju.P., Popkov R.A., Strekalov S.S. Veter, volny $i$ morskiye porty [Wind, waves and sea ports]. Leningrad. Gidrometeoizdat, 1986. 264 p. (rus)

17. Holthuijsen L.H. Waves in oceanic and coastal waters. Cambridge University Press. Cambrige, 2007. 236 p.

18. Booij N., Haagsma I.J., Holthuijsen L., Kieftenburg A., Ris R., van der Westhuysen A., Zijlema M. SWAN Cycle III version 40.51. User manual. The Netherlands, 2009. 67 p.

19. Hasselmann K., Barnett T.P., Bouws E., Walden $H$. Measurements of wind-wave growth and swell decay during the Joint North Sea Wave Project (JONSWAP). Ergnzungsheft zur Deutschen Hydrographischen Zeitschrift Reihe. 1973. No. 12. 95 p.

20. Aelbrecht D. ARTEMIS 3.0: A finite element model for predicting wave agitation in coastal areas and harbours including dissipation. Computer modelling of seas and coastal regions III. Boston, 1997. Pp. 343-352.

21. Berkhoff J.C. Computation of combined refractiondiffraction. 13th Coastal Engineering Conference. New York, 1972. Vol. 1. Pp. 471-490.

22. Berkhoff J. C. Mathematical models for simple harmonic linear water waves: wave diffraction and refraction. Delft: Hydraulic Laboratory, 1976. 102 p.

23. Hervouet J. M. TELEMAC, a hydroinformatic system. La Houille Blanche. 1999. No. 3-4. Pp. 21-28.

Izmail Kantardgi,

+7(903)5337830; kantardgi@yandex.ru

Mark Zheleznyak, +818058441091; zheleznyak.m@gmail.com
$254 \mathrm{C}$.

14. СП 38.13330.2012. Нагрузки и воздействия на гидротехнические сооружения (волновые, ледовые и от судов)». Актуализированная редакция СНиП 2.06.04-82*. М.: Минрегион России, 2011. 116 с.

15. РД 31.33.02-81. Методические указания по определению ветровых и волновых условий при проектировании морских портов. М.: СоюзморНИИпроект, 1981. $91 \mathrm{c.}$

16. Галенин Б.Г., Дугинов Б.А., Кривицкий С.В., Крылов Ю.М., Подмогильный И.А., Поляков Ю.П., Попков Р.А., Стрекалов С.С. Ветер, волны и морские порты. Л.: Гидрометеоиздат, 1986. 264 с.

17. Holthuijsen L.H. Waves in oceanic and coastal waters Cambrige: Cambridge University Press, 2007. 236 p.

18. Booij N., Haagsma I.J., Holthuijsen L., Kieftenburg A., Ris R., van der Westhuysen A., Zijlema M. SWAN Cycle III version 40.51. User manual. The Netherlands, 2009. $67 \mathrm{p}$.

19. Hasselmann K., Barnett T.P., Bouws E., Walden H. Measurements of wind-wave growth and swell decay during the Joint North Sea Wave Project (JONSWAP) // Ergnzungsheft zur Deutschen Hydrographischen Zeitschrift Reihe. 1973. № 12. 95 p.

20. Aelbrecht D. ARTEMIS 3.0: A finite element model for predicting wave agitation in coastal areas and harbours including dissipation // Computer modelling of seas and coastal regions III. Boston, 1997. Pp. 343-352.

21. Berkhoff J.C. Computation of combined refractiondiffraction // 13th Coastal Engineering Conference. New York, 1972. Vol. 1. Pp. 471-490.

22. Berkhoff J. C. Mathematical models for simple harmonic linear water waves: wave diffraction and refraction. Delft: Hydraulic Laboratory, 1976. 102 p.

23. Hervouet J. M. TELEMAC, a hydroinformatic system // La Houille Blanche. 1999. № 3-4. Pp. 21-28.

Измаил Григорьевич Кантаржи, $+7(903) 5337830$

эл. почта: kantardgi@yandex.ru

Марк Иосифович Железняк, +818058441091; эл. почта: zheleznyak.m@gmail.com 